\author{
한우의 도체중, 배장근단면적 및 근내지방도의 유전모수 추정방법 \\ 이 득 환 \\ 한경대학교
}

\title{
Methods for Genetic Parameter Estimations of Carcass Weight, Longissimus Muscle Area and Marbling Score in Korean Cattle
}

\author{
D. H. Lee
}

Hankyong National University

\begin{abstract}
This study is to investigate the amount of biased estimates for heritability and genetic correlation according to data structure on marbling scores in Korean cattle. Breeding population with 5 generations were simulated by way of selection for carcass weight, Longissimus muscle area and latent values of marbling scores and random mating. Latent variables of marbling scores were categorized into five by the thresholds of $0,1,2$, and 3 SD(DS1) or seven by the thresholds of $-2,-1,0,1,2$, and $3 \mathrm{SD}(\mathrm{DS} 2)$. Variance components and genetic parameters(Heritabilities and Genetic correlations) were estimated by restricted maximum likelihood on multivariate linear mixed animal models and by Gibbs sampling algorithms on multivariate threshold mixed animal models in DS1 and DS2. Simulation was performed for 10 replicates and averages and empirical standard deviation were calculated. Using REML, heritabilitis of marbling score were under-estimated as 0.315 and 0.462 on DS1 and DS2, respectively, with comparison of the parameter(0.500). Otherwise, using Gibbs sampling in the multivariate threshold animal models, these estimates did not significantly differ to the parameter. Residual correlations of marbling score to other traits were reduced with comparing the parameters when using REML algorithm with assuming linear and normal distribution. This would be due to loss of information and therefore, reduced variation on marbling score. As concluding, genetic variation of marbling would be well defined if liability concepts were adopted on marbling score and implemented threshold mixed model on genetic parameter estimation in Korean cattle.
\end{abstract}

(Key words : Categorical data, Threshold model, Variance component, Modeling, Hanwoo)

$\begin{aligned} \text { I 서 론 } & \text { 어서 1996년 가을 이전 출생 검정송아지들에 대 } \\ & \text { 하여는 거세를 실시하지 않고 후대검정을 실시한 } \\ 1990 \text { 년대 이후 우리나라 한우의 개량은 육량 } & \text { 반면에 이후 후대 검정송아지들에 대하여 거세를 } \\ \text { 보다는 육질중심의 개량에 크게 관심을 기울여 } & \text { 실시하여 후대검정을 실시하여 왔다. 한편 거세 } \\ \text { 왔으며 따라서 한우 종축선발을 위한 대표적인 } & \text { 우와 비거세우 간에 근내지방의 침착정도는 상당 } \\ \text { 개량형질로써 도축시 측정 가능한 육질관련 형질 } & \text { 한 차이가 있는 것으로 알려져 있으며 비거세우 } \\ \text { 에 크게 비중을 두었고 이러한 형질을 기준으로 } & \text { 에 있어서 근내지방의 침착정도를 점수화하여 표 } \\ \text { 종축선발을 실시하여 왔다. 실제로 한우 후대검 } & \text { 현한 근내지방도의 점수분포를 살펴보면 1점이 } \\ \text { 정을 통한 종모우 선발에 기준이 되는 형질들은 } & 45 \%, 2 \text { 점이 24\%으로 자료분포에 있어서 정규성 } \\ \text { 도체중, 배장근단면적 및 근내지방도 등이었다 } & \text { 에 크게 위배된 분포특성을 보이고 있는 것으로 } \\ \text { (축산기술연구소, 2003). 한우 후대검정방법에 있 } & \text { 조사되었다(이 등, 2001). 반면에 23차 한우 후대 }\end{aligned}$

Corresponding author: D. H. Lee, Dept. of Animal Life and Resources, Hankyong National University, Seokjong-dong 67, Ansung-si, Kyonggi-do, 456-749, Korea, Tel : 031-670-5091, Fax : 031-676-5091, E-mail : dhlee@hnu.hankyong.ac.kr 
검정 이후부터 실시한 거세 검정우들의 근내지방 도 자료를 살펴보면 정규성에 가까이 접근하는 분포특성을 보이고 있었다(윤 등, 2002). 주요 개 량의 대상이 되는 이러한 형질들에 대한 유전분 석은 현재까지 각 자료의 정규분포 특성을 갖는 다는 가정하에 개체들의 유전효과를 포함하는 단 형질 선형모형을 설정하고 유전분석을 실시하여 왔다(축산기술연구소, 2003). 하지만 정규성에 크 게 위배되는 범주형 자료의 유전분석을 선형모형 의 가정하에 실시하는 것은 분석의 오류를 범할 수 있다고 하겠다. 이론적으로 이산형 자료특성 을 갖는 형질에 있어서 유전능력 평가는 범주형 모형하에서 실현가능하며(Gianola and Foulley, 1983) 이러한 모형에서의 분석방법들에 대한 연 구가 다수 수행되었다(Varona 등, 1999; RamirezValverde 등, 2001). 일반적으로 범주형 모형은 순 서화된 범주형자료(Ordered categorical data)에서 정규 분포하는 잠재변수가 존재한다(Wright, 1934)는 가정하에 잠재변수를 생성하고 이를 이 용한 혼합모형식을 설정하여 유전분석을 실시하 는 방법인데 일반적으로 범주형자료에 있어서 유 전변이는 연속변량이며 정규분포한다는 가정하에 선형모형을 설정하여 변이를 추정할 경우와 비교 할 때, 범주형 모형에 의한 유전변이가 1 2배 크게 추정된다고 보고하였다(Matos 등, 1997, Val Tassel 등, 1999; Phocas and Laoe, 2003). 하지만 자료의 분포특성에 따른 편의추정의 크기에 대한 연구는 아직 미진한 상태이며 그 원인에 대한 명 확한 해석이 미흡한 실정이다. 특히 현재 한우 종모우 선발을 위하여 고려되고 있는 형질들에 대한 종축평가에 있어서 연속변량으로 간주되는 도체중 및 배장근단면적과 이산형이며 비정규분 포의 특성을 갖는 근내지방도에 대한 유전변이 추정에 있어서 다수의 형질을 동시에 평가할 수 있는 방법에 대한 연구가 선행되어야 한다. 따라 서 본 연구는 한우개량에 있어서 육질에 크게 영 향하며 순서화된 범주형 자료로 조사되는 근내지 방도 및 연속형 변량으로 간주되는 도체중 및 배 장근단면적에 있어서 비거세우에서 조사된 근내 지방도의 경우와 거세우에서 조사된 근내지방도 의 경우에 다형질 선형모형과 범주형 모형에서 유전변이의 차이를 알아보고 범주형 자료의 특성
에 따른 유전변이의 크기를 제시함으로써 실제 한우 종모우의 유전능력 평가를 실시하기 위한 최적 분석모형 및 분석방법을 알아보고 이를 한 우 종모우 평가방법에 활용하기 위한 참고자료로 제시하고자 본 모의실험을 통한 연구를 수행하였 다.

\section{ㅍ 분석방법}

\section{1. 모의시험 자료생성}

본 연구를 위해 수행한 모의실험은 현실 타 당성에 근접한 육종계획을 수립하고 이에 대한 검정모형을 설정하여 Monte Carlo 모의실험을 실시하였다. 본 모의실험에 육질개량을 위하여 고려된 형질들은 실제 한우개량을 위한 선발형 질로써 도축하여 조사되는 도체중(CW), 배장근 단면적(LMA), 및 근내지방도(MS) 등이었다.

본 모의실험에 있어서 각 세대별 종축선발은 3 가지 고려된 형질들에 대한 다변량 혼합개체모 형식으로부터 추정된 각 형질별 육종가(최적선형 불편예측치)에 상대적 경제 가중치를 동일하게 부여하여 종축을 선발하였다. 종축선발을 위한 모의실험은 숫소 100 두 및 암소 5,000 두를 기초축 으로 하여 매 세대 수컷 50두와 암컷 2,000두를 선발하여 5 세대 동안 진행되었고 출생년도는 세 대와 중첩되도록 설계하였으며 개체별 혈연관계 를 고려하였다. 세대간격은 수컷의 경우 보증종 모우로 선발된 후에 정액을 활용한다는 가정하에 6 세부터 10 세까지 이용하였으며 암컷의 경우는 2 세부터 6세까지 이용하였다. 본 모형에서 자료생 성을 위하여 고려한 고정효과는 암컷과 수컷으로 구분한 성별 효과, 5 세대에 걸쳐 세대와 중첩되고 평균 세대당 10 수준으로 하여 총 50 수준을 임의 배정한 검정년도 - 계절 효과를 고려하였다. 기초 집단에 대한 도체중, 배장근단면적 및 근내지방 도의 잠재변수에 대한 평균은 각각 $300 \mathrm{~kg}, 100 \mathrm{~cm}^{2}$ 및 50 으로 가정하였고 각각의 형질들에 대한 분 산 -공분산 성분은 Table 1에 제시된 값을 모수로 이용하였다. 각각의 고정효과는 각 형질별 평균 을 중심으로 $\pm 2 \mathrm{SD}$ 이내의 균일분포함수에서 임의 생성하였다. 육종가에 대한 자료생성은 
Falconer와 Mackay(1996)가 제시한 infinitestimal genetic model에 기초하여 다음과 같이 생성하였다.

Table 1. Parameters of genetic and residual (co)variances for simulation

\begin{tabular}{llll}
\hline & \multicolumn{1}{c}{ CW } & LMA & MS $_{\mathrm{L}}$ \\
\hline \hline CW & $250(750)^{(1)}$ & 25 & 15 \\
LMA & 100 & $20(50)$ & 2 \\
MS $_{\mathrm{L}}$ & 5 & 7 & $10(10)$ \\
\hline
\end{tabular}

Values in blanket and below diagonal are residual (co)variances and values upper diagonal are genetic (co)variances; CW: carcass weight, LMA: Longissimus Muscle Area, $\mathrm{MS}_{\mathrm{L}}$ : Liability scale of marbling score

$$
a_{0}=0.5 a_{s}+0.5 a_{d}+m
$$

여기서 $a_{0}$ 는 자손의 해당 형질에 대한 육종 가이고 $a_{s}$ 는 부의 육종가 $a_{d}$ 는 모의 육종가 및 $m$ 은 Mendelian sampling contribution이다.

부모를 모르는 기초집단의 경우 3 가지 도축 형질에 대한 개체의 육종가는 평균이 “0”이고 분산이 $\mathrm{G}$ 인 다변량 정규분포함수 $(a \sim M V N(0$, $G)$ )에서 생성하였으며 부모를 알 경우에는 상 기의 식 (1)에서 Mendelian sampling에 의한 기 여도 $m \sim \operatorname{MVN}\left(0,\left\{0.5-0.25\left[F_{s}+F_{d}\right]\right\} G\right)$ 을 고려 하여 생성하였다. 여기서 $F_{s}\left(F_{d}\right)$ 는 아비(어미)의 근교계수이며 $G$ 는 제시한 해당 형질들에 대한 선발을 가하기 전의 초기 유전 (공)분산성분이 다. 근교계수 추정방법은 Meuwissen과 Luo (1992)가 제시한 방법을 recursive algorithm으로 변형하여 계산하였다. 개체별 해당형질들에 대 한 육종가 생성은 다형질 정규분포함수에서 Cholesky 분해방법으로 다수의 형질을 동시에 임의 생성하였으며 임의오차에 대한 생성은 $e$ $\sim \operatorname{MVN}(0, \mathrm{I} \otimes \mathrm{R})$ 의 가정하에 다형질 정규분포 함수에서 동시 생성하였다. 또한 각 형질별 반 복기록이 없는 것을 가정하였다. 본 모형을 식 으로 표현하면 다음과 같다.

$$
y_{i m}=\mu_{i}+\operatorname{Sex}_{i j}+Y S_{i k}+a_{i m}+e_{i m}
$$

여기서 $y_{i}$ 는 $i$ 형질에 대한 $m$ 개체의 관측치, $\mu_{i}$ 는 $i$ 형질의 전체평균, $\operatorname{Sex}_{i}$ 는 $i$ 형질의 $j$ 성에 대한 고정효과(수준 $=2), Y S_{i k}$ 는 $i$ 형질의 $k$ 년 도 - 계절에 대한 고정효과(수준 50), $a_{i m}$ 은 $i$
형질의 $m$ 개체의 임의 상가적 유전효과 및 $e_{m}$ 은 $i$ 형질의 $m$ 개체에 대한 임의 환경효과이다.

상기의 모형으로부터 세대별 모든 개체에 대 하여 모수 및 생성된 모수를 모형에 적합시켜 생성된 표현형 자료를 이용하여 표현형 순위 및 육종가를 추정하였다. 종축의 육종가 추정방법 은 상기의 모형에 적합하여 매 세대 preconditioned conjugate gradient 방법을 이용한 다변량 BLUP 추정(Tsuruta 등, 2001)방법으로 추정하였 으며 각 형질별 육종가를 표준화한 값에 동일 가중치를 부여하여 선발지수식을 계산하였고 지수에 의한 상위 종축을 선발하였으며 선발된 종축은 임의교배를 실시하였다. 최종 생성된 자 료를 이용하여 범주형 자료를 생성하기 위하여 표준화한 근내지방도 잠재변수에 대하여 0,1 , 2 , 및 $3 \mathrm{SD}$ 의 값을 임계값으로 하여 $1 \sim 5$ 점의 근내지방도(순서화된 범주형자료)를 생성하였 고(DS1) 또한 동일한 근내지방도 잠재변수에 대하여 $-2,-1,0,1,2$ 및 $3 \mathrm{SD}$ 를 임계값으로 한 1 7점의 근내지방도 자료(DS2)를 생성하였 다. 본 모의실험은 10 반복을 실시하여 모수와 추정치와의 차이를 계산하고 통계적 $\mathrm{t}$-검정를 통하여 추정의 정확도를 알아보았다.

\section{2. 분산성분 추정}

\section{(1) 선형 혼합개체모형에서 EM-REML}

근내지방도에 대하여 5단계로 점수화하여 표 현한 범주형 자료를 갖는 모의시험자료(DS1)와 7단계로 점수화한 모의시험자료(DS2)에 대하여 범주형 자료를 연속형 변량으로 가정하고 $\mathrm{CW}$ 와 LMA를 포함하는 다변량 혼합 개체모형을 설정하여 분산 - 공분 성분을 다음과 같은 모형 을 설정하여 추정하였다.

$$
\begin{aligned}
& {\left[\begin{array}{l}
\mathrm{y}_{1}{ }^{\prime} \\
\mathrm{y}_{2}{ }^{\prime} \\
\mathrm{y}_{3}{ }^{\prime}
\end{array}=\left[\begin{array}{ccc}
\mathrm{x}_{1} & 0 & 0 \\
0 & \mathrm{X}_{2} & 0 \\
0 & 0 & \mathrm{X}_{3}
\end{array}\right]\left[\begin{array}{l}
\beta_{1}{ }^{\urcorner} \\
\beta_{2}{ }^{\prime}+ \\
\beta_{3}{ }^{\prime}
\end{array}\right.\right.}
\end{aligned}
$$

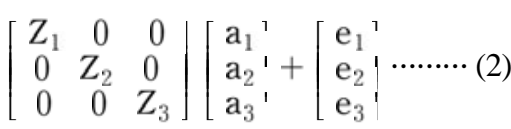

여기서 $\mathrm{y}_{1}, \mathrm{y}_{2}$ 및 $\mathrm{y}_{3}$ 는 각각 $\mathrm{CW}, \mathrm{LMA}$ 및 $\mathrm{MS}$ 에 대한 관측치이고 $\beta_{1}, \beta_{2}$ 및 $\beta_{3}$ 는 각각의 형 
질들에 대한 고정효과이며 $\mathrm{a}_{1}, \mathrm{a}_{2}$ 및 $\mathrm{a}_{3}$ 는 각각 의 형질들에 대한 동물개체의 유전능력를 나타 내는 임의효과이다. 임의효과에 대한 평균은 “0”으로 가정하고 이들의 분산 - 공분산 성분은 다음과 같이 가정하였다.

3가지 형질들의 상가적 유전효과를 포함하는 다변량 혼합 개체모형에서 EM-REML방법으로 임의변량에 대한 (공)분산 성분을 추정하였는데 추정의 수렴속도를 증가시키기 위하여 Aitken acceleration방법(Little and Rubin, 1987)으로 수 렴속도를 빠르게 구현하여 분석을 실시하였다.

\section{(2) 범주형 혼합개체모형에서 Gibbs sampling 방법}

다변량 범주형 혼합개체모형을 설정하고 Geman과 Geman(1984)이 제시한 Gibbs sampling algorithm과 Sorensen 등(1995)이 제시한 단형질 범주형 자료의 분석방법을 응용하였고 다수의 형질로 확장하는 이론에 대한 연구는 이(2002) 의 연구결과에 기초하여 실시하였다. 다변량 통계분석에서 연속형 종속변수는 도체중량, 배 장근단면적이고 순서화된 범주형 자료로써 근 내지방도를 범주형 모형을 설정하여 Bayesian inference의 일종인 Gibbs sampling 방법으로 분 산성분을 추정하였다. 분석모형에서 범주형 관 측치는 아래와 같이 주어진 범주구간내에 관측 되지 않는 잠재변수 $(u)$ 가 존재한다는 가정하에 잠재변수를 생성하였다. 즉, 범주형 자료의 $i$ 번 째 관측치에서 $y_{i}=\lambda$, if $t_{\lambda-1}<u_{i} \leq t_{\lambda}$ 이며 $\lambda$ 은 범주형 자료 $1 \sim \mathrm{C}$ 의 구간내에 관측된 관측치 이며 각각의 임계값에 대한 벡터 $t=\left(t_{1}, t_{2}, \cdots\right.$, $\left.t_{C-1}\right)^{\prime}$ 는 $-\infty=t_{0}<t_{1}<\cdots<t_{C-1}<t_{C}=\infty$ 의 범위내 에 존재한다. 여기서부터 생성된 근내지방도에 대한 잠재변수는 연속형 변량으로써 연속형 변량 인 $\mathrm{CW}$ 및 $\mathrm{LMA}$ 를 고려하여 다형질 혼합개체모
형을 설정하고 유전분석을 실시하였다. 여기서 분석모형은 모의실험을 위한 자료생성시 설정 된 모형과 동일하게 분석모형을 설정하였다. 즉, 3 가지 종속변수에 대한 벡터를 U로 정의한

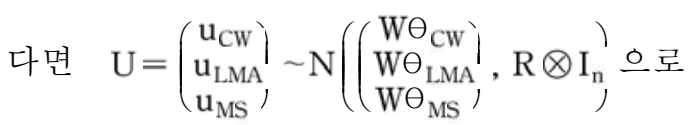
여기서 $R$ 은 $3 \times 3$ 크기의 잔차분산 - 공분산성분 행렬이고 $\theta$ 는 각 형질별 위치모수이며 $W$ 는 이에 대응되는 계수행렬이다. 근내지방도 관측 치에 대한 잠재변수는 다음과 같은 분포특성을 갖는다. 즉 근내지방도가 $\mathrm{i}$ 번째 형질이고 $\mathrm{j}$ 번째 관측치가 $\lambda$ 이라면 이에 대한 잠재변수는 다음 의 확률변수 특성을 갖는 것으로 가정하였다.

$$
\begin{aligned}
& \mathrm{f}\left(\mathrm{u}_{\mathrm{ij}} \mid \mathrm{y}_{\mathrm{ij}}=\lambda, \mathrm{u}_{-\mathrm{ij}}, \ominus, \mathrm{R}, \mathrm{t}\right)=
\end{aligned}
$$

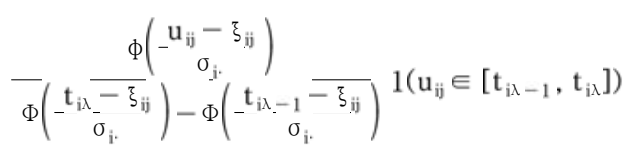

따라서 주어진 임계값 기타형질에 대한 관측 치, 지역모수, 잔차분산 및 관측치 $\lambda$ 에서 잠재 변수의 대한 조건확률분포는 다음과 같이 표현 할 수 있다.

$$
\mathrm{u}_{\mathrm{ij}} \mid \mathrm{y}_{\mathrm{ij}} \lambda, \mathrm{u}_{-\mathrm{ij}}, \ominus, \mathrm{r}, \mathrm{t} \sim \mathrm{TN}_{\mathrm{t}_{\mathrm{i}-1, \mathrm{t}}, \mathrm{t}_{\mathrm{i}}}\left(\xi_{\mathrm{ij}}, \sigma_{\mathrm{i}}^{2}\right) \cdots
$$

여기서 $u_{-i j}$ 는 $u_{i j}$ 를 제외한 기타 잠재변수 및 연 속변량을 갖는 형질들에 대한 관측치를 의미하 고 $\Phi(\cdot)$ 와 $\Phi(\cdot)$ 는 정규분포에서 확률밀도함 수(probability density function)와 누적밀도함수 (cumulated density function)를 의미하며, $T N$ 는 절단형 정규분포함수를 의미한다. 또한 절단 형 정규분포함수에서 평균 $\xi_{i j}=w_{i j}{ }_{i j} \theta_{i}+R_{i(-i)}$ $R_{(-i)(-i)}^{-1} e_{-i j}$ 와 분산 $\sigma_{i \cdot}^{2}=r_{i i}-R_{i(-i)} R_{(-i)(-i)}^{-1}$ $R_{(-i) i}$ 으로 계산된다. 여기서 잔차분산 $R=$ $\left[\begin{array}{ll}R_{i i} & R_{i(-i)} \\ R_{(-i) i} & R_{(-i)(-i)}\end{array}\right]$ 이다.

임의로 생성된 잠재변수에 대한 변이의 크기 와 중심치를 결정해야 하는 문제(Identifiability) 가 발생한다. 이를 위하여 Sorensen 등(1995)은 임계값의 하나를 "0"으로 제한하고 잔차분산을 "1"로 제한하는 방법을 사용할 수 있다고 하였 는데 본 연구에서는 2 개의 인접한 임계값을 "0" 
과 “1”로 제한하여 잠재변수를 생성하였다 (VanTassel 등, 1998).

Gibbs sampling에 의한 임계값의 생성은 Sorensen 등(1995)이 제시한 방법으로 다음과 같이 생성 하였다.

$\mathrm{t}_{\mathrm{i} \lambda}^{\mathrm{n}} \mid \ominus, \mathrm{R}, \mathrm{G}, \mathrm{t}_{-\mathrm{i} \lambda}, \mathrm{U}, \mathrm{y}^{0} \sim \mathrm{UN}\left(\max \left(\max _{\mathrm{j}}\left(\mathrm{u}_{\mathrm{ij}}^{*}\right) \mathrm{y}_{\mathrm{ij}}\right.\right.$ $\left.\left.=\lambda), t_{i \lambda-1}^{n}\right), \min \left(\min _{j}\left(u_{i j}^{*} \mid y_{i j}=\lambda+\right), t_{i \lambda+1}^{n-1}\right)\right)$

여기서 $\mathrm{UN}$ 은 균일분포함수를 의미한다. 위치모 수(Location parameter)와 이산모수(dispersion parameter)에 대한 사후분포특성을 규명하기 위해 서는 이들 모수에 대한 사전분포 특성을 정의 해야 한다. 본 연구에서는 각 모수에 대한 사 전분포를 다음과 같이 가정하였다.

(a) $f(\beta) \propto$ cons

(b) $f($ a $\mid \mathrm{G}) \sim \mathrm{N}(0, \mathrm{G} \otimes \mathrm{A})$

여기서 $G$ 는 3 가지 형질들에 대한 $3 \times 3$ 유전 분산 - 공분산 행렬이고 $A$ 는 개체들간의 혈연계 수 행렬이다. 유전분산-공분산 성분과 환경 분산 - 공분산 성분에 대한 사전정보를 모르기 때문에 Jeffrey의 noninformative priors(Gelman et al., 1995)를 적용하여 아래와 같이 가정하였다.

(c) $f(R) \propto|R|^{-k / 2}$

(d) $f(G) \propto|G|^{-k}$

각 모수에 대한 사전정보에 따라 사후조건확 률분포는 지역모수의 경우 Van Tassel 등(1998) 이 제시한 방법에 따라 다변량 정규분포 함수 에서 Gibbs sampler를 적용하였으며 분산-공분 산 성분은 inverted Wishart 분포함수에서 생성 하였다. 각 모수에 대한 Gibbs sampler를 적용하 기 위한 모수의 초기치로써 임계값의 초기치는 0 부터 1 씩 증가하여 부여하였으며, 지역모수의 초기치는 각 요인들의 수준별 단순평균을 적용 하였고, 분산 - 공분산 성분은 모의실험자료를 생성하기 위하여 사용된 모수를 적용하였다.

\section{III 결과 및 고찰}

1998년부터 2002년까지 한우 검정우의 거세
를 통한 후대검정에서 조사된 근내지방도의 분 포는 Fig. 1에 제시된 바와 같이 정규분포에서 벗어나고 있었다(윤 등, 2002). 하지만 한우 비 거세우을 이용한 후대검정에서 조사된 근내지 방도의 분포(이 등, 2001)와 비교해 볼 때 비거 세우에서 보다 정규성에 상당히 근접하고 있음 을 알 수 있었다. 따라서 본 연구에 이용된 모 의실험 자료 역시 범주형 자료인 근내지방도의 생성을 비거세우의 자료분포 및 거세우에서의 자료분포와 유사하게 생성하였다. 모의실험을 통하여 생성된 근내지방도에 대한 자료의 분포 는 5 가지 범주로 조사된 경우(DS1)에 상당히 오른쪽으로 치우친 분포(왜도 $=0.94)$ 인 반면에 $\mathrm{DS} 2$ 의 경우에는 정규분포에 상당히 접근하는 분포특성을 갖도록 구성하였다(Table 2).

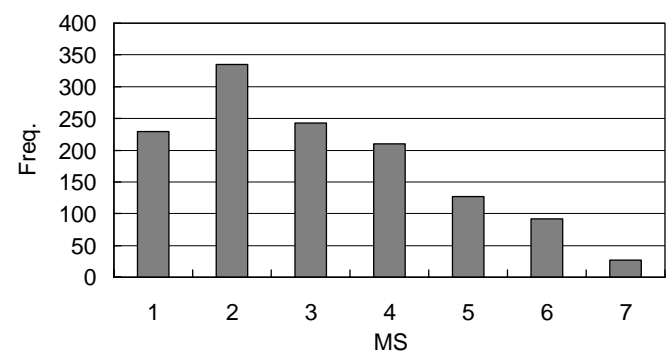

Fig. 1. Frequency of marbling scores(MS) of Hanwoo steers on progeny tests from 1998 to 2002.

Table 2. Information of distributions for linear and categorical traits on pooled simulated data(replicates $=10$ )

\begin{tabular}{|c|c|c|c|c|c|}
\hline & Mean & SD & $\mathrm{CV}$ & Skewness & Kurtosis* \\
\hline$\overline{\mathrm{CW}}$ & 310.83 & 32.96 & 10.61 & $-0 . \overline{00}$ & $-0 . \overline{02}$ \\
\hline LMA & 102.15 & 8.69 & 8.50 & -0.01 & -0.02 \\
\hline $\mathrm{MS}_{\mathrm{L}}$ & 51.83 & 4.90 & 9.45 & -0.00 & -0.03 \\
\hline $\mathrm{MS}_{5}$ & 1.68 & 0.80 & 47.33 & -0.94 & -0.21 \\
\hline $\mathrm{MS}_{7}$ & 3.47 & 1.07 & 31.00 & -0.01 & -0.26 \\
\hline
\end{tabular}

모의실험을 통하여 얻어진 자료에 대하여 REML방법과 Gibbs sampling 방법으로 추정된 (공)분산 성분과 이를 이용하여 계산된 유전력 및 유전상관 추정결과를 모수와 비교하는 방법 
으로 분석방법에 다른 추정의 정확도를 비교하 였다. 선형모형에서 REML방법으로 추정된 분 산 및 공분산 성분은 Aitken 가속알고리즘을 적용함으로써 수렴속도를 높일 수 있었다. Gibbs sampling에 의한 각 모수의 사후분포에 대한 안정화는 1,000회 Gibbs sampling 이내에 서 빠르게 안정화되었다. 특히 근내지방도의 잠재변수 생성을 위하여 2개의 임계값을 제한 함으로써 모수를 하나 줄임으로써 기타 임계값 에 대한 Gibbs Samples이 빠르게 안정화되어 수렴하는 것을 알 수 있었다. 또한 이들 사후 분포에 대한 평균으로 표현한 추정치는 모수와 차이가 없는 것을 알 수 있었다(Table 3). 여기 서 잠재변수의 Identifiability를 위한 제한을 가 할 때 잔차분산을 “ 1 ”로 제한하는 방법 또는

Table 3. Means and empirical standard deviations of posterior means of thresholds by Gibbs sampler in simulated data(replicates $=10$ )

\begin{tabular}{ccccccc}
\hline \multirow{2}{*}{ Threshold Param. } & \multicolumn{2}{c}{ DS with } & 5 Cat. & & DS with & 7 Cat \\
\cline { 6 - 7 } \cline { 6 - 6 } & & Mean & SD & & Mean & SD \\
\hline \hline 3 & 2.000 & 2.015 & 0.033 & 1.957 & 0.020 \\
4 & 3.000 & 3.059 & 0.078 & 3.026 & 0.034 \\
5 & 4.000 & N/A & & 4.091 & 0.057 \\
6 & 5.000 & N/A & & 5.188 & 0.107 \\
\hline
\end{tabular}

잔차분산의 크기를 변환하는 방법(Lee, 2002)과 비교해 보면, 이산형 자료가 하나일 경우에는 2 개의 인접한 임계값을 제한하는 방법은 프로 그램이 용이하고 기타 임계값에 대한 사후분포 의 수렴이 빨랐는데 이는 모수가 하나 감소하 였기 때문인 것으로 사료된다.

Table 4에는 5구간으로 조사된 근내지방도를 포함하는 자료(DS1)에서 REML 방법과 Gibbs 방 법으로 추정된 모수의 결과를 비교하여 제시하 였다. Table 3에 제시된 바와 같이 일반 선형혼 합모형에서 REML 방법으로 분석한 유전력의 추정치는 연속변량이며 선형인 도체중 및 배장 근단면적에서 모수와의 $\mathrm{t}$ - 검정 결과, 유의적인 차이가 없는 것으로 분석되었으며 또한 이들 형 질들 간의 유전상관 및 잔차상관에 있어서도 모 수와 유의적인 차이가 없는 것으로 추정되었다. 반면에 근내지방도의 유전력 추정치는 모수와 비교하여 유의적으로 낮게 추정되었다 $(\mathrm{P}<0.01)$. 이는 타 연구결과와 일치하는 결과로써 과소 추 정되는 정도는 자료의 특성에 따라 차이가 있는 것으로 사료된다. 근내지방도의 연속변량과의 유전상관 추정치는 모수와 유의적인 차이가 없 는 것으로 추정되었으나 잔차상관의 경우에는 모수보다 다소 낮게 추정되었다. 이는 형질들 간 의 잔차상관이 적어지고 있는 것으로 사료되지 만 이에 대한 연구가 필요할 것으로 생각한다.

Table 4. Means, empirical standard deviations of Estimates of generic parameters for carcass weight, longissimus muscle area, marbling score with 5 categories by two different models and algorithms(replicates=10)

\begin{tabular}{|c|c|c|c|c|c|c|c|c|c|}
\hline & \multirow{2}{*}{ Param. } & \multicolumn{4}{|c|}{ REML with LM } & \multicolumn{4}{|c|}{ GIBBS with TM } \\
\hline & & Est. & SD & Diff. & $\mathrm{P}$ value & Est. & SD & Diff. & $\mathrm{P}$ value \\
\hline \multicolumn{10}{|l|}{ Heritability } \\
\hline $\mathrm{CW}$ & 0.250 & 0.254 & 0.017 & 0.004 & 0.472 & 0.257 & 0.017 & 0.007 & 0.226 \\
\hline LMA & 0.286 & 0.288 & 0.013 & 0.002 & 0.667 & 0.285 & 0.013 & -0.001 & 0.900 \\
\hline MS & 0.500 & 0.315 & 0.011 & -0.185 & 0.000 & 0.492 & 0.017 & -0.008 & 0.186 \\
\hline \multicolumn{10}{|c|}{ Genetic correlation } \\
\hline CW-LMA & 0.354 & 0.360 & 0.032 & 0.007 & 0.522 & 0.366 & 0.032 & 0.012 & 0.245 \\
\hline CW-MS & 0.300 & 0.297 & 0.044 & -0.003 & 0.808 & 0.322 & 0.046 & 0.022 & 0.158 \\
\hline LMA-MS & 0.141 & 0.134 & 0.043 & -0.007 & 0.605 & 0.158 & 0.045 & 0.017 & 0.263 \\
\hline \multicolumn{10}{|c|}{ Residual correlation } \\
\hline CW-LMA & 0.516 & 0.512 & 0.013 & -0.004 & 0.349 & 0.511 & 0.012 & -0.006 & 0.180 \\
\hline CW-MS & 0.058 & 0.050 & 0.014 & -0.008 & 0.115 & 0.048 & 0.018 & -0.010 & 0.111 \\
\hline LMA-MS & 0.313 & 0.241 & 0.015 & -0.072 & 0.000 & 0.303 & 0.020 & -0.010 & 0.146 \\
\hline
\end{tabular}


Table 5. Means, empirical standard deviations of estimates of generic parameters for carcass weight, longissimus muscle area, marbling score with 7 categories by two different models and algorithms(replicates $=10$ )

\begin{tabular}{|c|c|c|c|c|c|c|c|c|c|}
\hline & \multirow{2}{*}{ Param. } & \multicolumn{4}{|c|}{ REML with LM } & \multicolumn{4}{|c|}{ GIBBS with TM } \\
\hline & & Est. & SD & Diff. & $\mathrm{P}$ value & Est. & SD & Diff. & $\mathrm{P}$ value \\
\hline \multicolumn{10}{|l|}{ Heritability } \\
\hline $\mathrm{CW}$ & 0.250 & 0.256 & 0.017 & 0.006 & 0.272 & 0.258 & 0.017 & 0.008 & 0.190 \\
\hline LMA & 0.286 & 0.284 & 0.013 & -0.001 & 0.765 & 0.286 & 0.013 & 0.000 & 0.968 \\
\hline MS & 0.500 & 0.462 & 0.015 & -0.038 & 0.000 & 0.500 & 0.016 & 0.000 & 0.936 \\
\hline \multicolumn{10}{|c|}{ Genetic correlation } \\
\hline CW-LMA & 0.354 & 0.365 & 0.031 & 0.012 & 0.265 & 0.366 & 0.031 & 0.013 & 0.227 \\
\hline CW-MS & 0.300 & 0.309 & 0.039 & 0.009 & 0.508 & 0.307 & 0.040 & 0.007 & 0.580 \\
\hline LMA-MS & 0.141 & 0.151 & 0.039 & 0.009 & 0.473 & 0.151 & 0.040 & 0.009 & 0.471 \\
\hline \multicolumn{10}{|c|}{ Residual correlation } \\
\hline CW-LMA & 0.516 & 0.511 & 0.012 & -0.006 & 0.168 & 0.511 & 0.012 & -0.006 & 0.166 \\
\hline CW-MS & 0.058 & 0.047 & 0.016 & -0.011 & 0.056 & 0.052 & 0.017 & -0.006 & 0.284 \\
\hline LMA-MS & 0.313 & 0.283 & 0.015 & -0.030 & 0.000 & 0.308 & 0.017 & -0.005 & 0.350 \\
\hline
\end{tabular}

반면에 7개의 범주로 구성된 근내지방도를 포함 하는 자료(DS2)에서 유전력 추정치를 살펴보면 (Table 5) 근내지방도를 선형으로 간주하고 REML 방법으로 추정한 근내지방도의 유전력은 모수 0.500 보다 0.038 이 적은 0.462 으로 추정되었 는데 이는 5 개의 범주형 자료의 근내지방도를 포 함하는 DS1에서의 REML 방법에 의한 유전력 추 정치 0.315 보다는 다소 높고 모수에 근접한 추정 치이었다. REML 방법에 의한 유전상관 및 잔차 상과 추정치는 DS1에서와 유사한 경향을 보였지 만 편의된 정도의 크기는 DS1 보다는 다소 낮은 것을 알 수 있었다. 반면에 Gibbs Sampling 방법 으로 각 모수의 사후 분포함수에 대한 평균치로 예측한 추정치는 유전력, 유전상관 및 잔차상관 모두에서 모수와 유의적인 차이가 없는 것을 알 수 있었다. 따라서 범주형자료에 대한 유전분석 을 실시할 때, 이들 자료를 선형으로 간주하고 유 전분석하는 것은 실제 모수보다 과소 추정될 수 있으며 그 크기는 범주형 자료의 크기 및 분포특 성에 따라 다르다는 것을 알 수 있었다. 반면에 이들 자료를 이산형으로 간주하고 잠재변수가 존 재한다는 가정하에 임계형 모형을 설정하고 유전 분석을 실시하면 모수에 근접한 추정치를 얻을 수 있음을 알 수 있었다. 따라서 이러한 자료에 대한 유전분석을 실시할 때, 임계형 모형이 타당 할 것으로 사료되었다.

$$
\text { IV 요 약 }
$$

한우 종모우 선발을 위한 유전능력 평가에서 고려되는 형질들 중 이산형 형태로 조사되는 근 내지방도의 유전변이가 추정방법에 따라 어느 정도 차이가 있는지 알아보기 위한 모의실험을 실시하였다. 모의실험 자료는 연속변량으로 간 주되는 도체중 및 배장근단면적과 근내지방도의 잠재변수를 다변량 정규분포함수에서 생성하였 고 근내지방도의 잠재변수를 이용하여 특정 임계 값을 중심으로 순서화된 근내지방도 점수로 변환 하였다. 근내지방도의 점수 부여방법으로써 비거 세우에서 조사된 근내지방도의 점수 $1 \sim 5$ 점 사이 에 정규분포에서 크게 어긋나는 분포특성을 갖도 록 자료(DS1)를 생성하였고 또한 한우 거세우에 서 현재 조사되고 있는 점수 $1 \sim 7$ 점 사이에 정규 분포에 좀더 접근한 분포특성을 갖는 모의 자료 (DS2)를 생성하였다. 분석방법간에 유전변이 추 정의 정확도를 알아보기 위하여 1) 생성된 이들 자료를 선형으로 간주하고 다형질 혼합 선형 개 체모형에서 REML 분석방법으로 유전변이를 추 정하였고 2) 특정 임계치를 중심으로 잠재변수가 존재한다는 가정하에 다형질 임계 개체 혼합모형 을 설정하여 Gibbs sampling 방법으로 유전변이를 추정하였다. 여기서 추정된 유전변이(유전력, 유 전상관 및 잔차상관)에 대하여 모수와의 차이를 
검정함으로써 편의되는 정도를 알아보았다. 모의 실험은 각 자료에 대하여 10 회 실시하였다.

분석결과, 근내지방도의 유전력 추정치는 DS1 에서는 다형질 임계개체혼합모형을 설정하여 Gibbs sampling 방법으로 모수에 대한 사후분포의 평균으로 계산한 결과 참값과 유의적인 차이가 없는 것으로 분석되었다. 반면에 근내지방도를 선형으로 간주하고 다형질 선형 개체혼합모형에 의한 유전력 추정치는 모수보다 매우 낮은 유전 력을 보였다(0.500 vs 0.315). 유전상관 추정치는 선형모형에서의 REML방법 또는 임계모형에서의 Gibbs sampling 방법에서 모두 모수와 유의적인 차이가 없는 것으로 분석되었으나 근내지방도의 잔차상관에 있어서 REML 방법으로 분석하였을 경우에 모수보다 낮게 추정되었다. 반면에 범주 형 모형에서는 모수와 추정치 간에 유의적인 차 이가 없는 것으로 분석되었다. 또한 7개의 범주형 으로 조사된 자료(DS2)에서 이들 추정치는 DS1 에서와 동일한 경향을 보였는데 그 편의 정도는 다소 적어지는 경향을 보였다. 따라서 이산형으 로 조사되는 근내지방도에 대한 유전변이를 추정 하기 위해서는 범주형 임계모형이 선형모형 보다 다소 정확한 추정을 할 수 있을 것으로 판단 되었다.

$$
\mathrm{V} \text { 사 사 }
$$

본 연구는 한국학술진흥재단 2003년 신진교 수연구지원사업(KRF-2003-003-F00029)의 연구비 지원에 의하여 수행되었음.

\section{$\mathrm{VI}$ 인 용 문 헌}

1. Falconer, D. S. and Mackay, T. F. C. 1996. Introduction to Quantitative Genetics. Edinburgh, Longman. $4^{\text {th }}$ Ed.

2. Gelman, A., Carlin, J. B., Stern, H. S. and Rubin, D. B. 1995. Bayesian data analysis. Chapman \& Hall.

3. Geman, S. and Geman, D. 1984. Stochastic relaxation, Gibbs distributions and the Bayesian restoration of images. IEEE Trans. Pattern Anal. Mach. Intel. 6:721-741.

4. Gianola, D. and Fouley, J. L. 1983. Sire evaluation for ordered categorical data with a threshold model. Genet. Sel. Evol. 15:201-244.
5. Lee, D. H. 2002. Investigation of biases for variance components on multiple traits with varying number of categories in threshold models using Bayesian inferences. Asian-Aust. J. Anim. Sci. 15:925-1070.

6. Little, R. J. A. and Robin, D. B. 2002. Statistical analysis with missing data. John Wiley \& Sons. Inc.

7. Matos, C. A. P., Thomas, D. L., Gianola, D., Tempelman, R. J. and Young, L. D. 1997. Genetic analysis of discrete reproductive traits in sheep using linear and nonlinear models: I. Estimation of genetic parameters. J. Anim. Sci. 75:76-87.

8. Meuwissen, T. H. E. and Luo, Z. 1992. Computing inbreeding coefficients in large populations. Genet. Sel. Evol. 24:305-313.

9. Phocas, F. and Laloe, D. 2003. Evaluation models and genetic parameters for calving difficulty in beef cattle. J. Anim. Sci. 81:933-938.

10. Ramirez-Valverde, R., Misztal, I. and Bertrand, J. K. 2001. Comparison of threshold vs linear and animal vs sire models for predicting direct and maternal genetic effects on calving difficulty in beef cattle. J. Anim. Sci. 79:333-338.

11. Sorensen, D. A., Andersen, S., Gianola, D. and Korsgaard, I. 1995. Bayesian inference in threshold models using Gibbs sampling. Genet. Sel. Evol. 27: 229-249.

12. Tsuruta, S., Misztal, I. and Stranden, I. 2001. Use of preconditioned conjugate gradient algorithm as a generic solver for mixed-model equations in animal breeding applications. J. Animal Sci. 1166-1172.

13. VanTassell, C. P., VanVleck, L. D. and Gregory, K. E. 1998. Bayesian analysis of twinning and ovulation rates using a multiple-trait threshold model and Gibbs sampling. J. Anim. Aci. 76: 2048-2061.

14. Varona, L., Misztal, I. and Bertrand, J. K. 1999. Threshold-linear versus linear-linear analysis of birth weight and calving ease using an animal model: I. Variance component estimation. J. Anim. Sci. 77:1944-2002.

15. 윤호백, 김시동, 나승환, 장은미, 이학교, 전광주, 이득환. 2002. 거세한우의 도체형질에 대한 유전 모수 추정. 한국동물자원과학회지 44(4):383-390.

16. 이득환. 2002. 다형질 Threshold 개체모형에서 missing 기록을 포함한 이산형 자료에 대한 Bayesian 분석. 한국 동물 자원 과학 회지 44(2):151-164.

17. 이득환, Misztal, I. and Bertrand, J. K. 2001. Bayesian analysis of carcass traits using multivariate threshold animal models and Gibbs sampling with missing records in Korean cattle. 한국동물자원과 학회지 43(1):9-22.

18. 축산기술연구소. 2003. 2003년 한우유전능력평가 보고서. 농촌진흥청 축산기술연구소.

(접수일자 : 2004. 2. 19. / 채택일자 : 2004. 7. 1.) 